\title{
LASER LIGHT STIMULATION EFFECTS ON SCORZONERA HISPANICA L. SEEDS GERMINATION, FIELD EMERGENCE AND PHOTOSYNTHETIC PIGMENTS CONTENT
}

\author{
Research note \\ Agata DZIWULSKA-HUNEK ${ }^{1 *}$, Marcela KRAWIEC ${ }^{2}$, Agnieszka SUJAK $^{1}$ \\ ${ }^{1}$ Department of Physics, University of Life Sciences, Akademicka 13, 20-950 Lublin, Poland \\ ${ }^{2}$ Department of Seed Sciences and Nursery, University of Life Sciences, \\ Leszczyńskiego 58, 20-068 Lublin, Poland
}

Received: December 2015; Accepted: February 2016

\begin{abstract}
The study presented herein concerns the effect of pre-sowing stimulation of scorzonera seeds with $\mathrm{He}-\mathrm{Ne}$ laser on germination capacity, field emergence of seedlings and the content of chlorophylls and carotenoids. Seeds of scorzonera cv. 'Duplex', from harvests of various years, dis-played variable quality expressed by their germination capacity. They were subjected to pre-sowing stimulation with $\mathrm{He}-\mathrm{Ne}$ laser light of the power of $40 \mathrm{~mW}$ and wavelength of $632.8 \mathrm{~nm}$, surface power density of $5 \mathrm{~mW} \cdot \mathrm{cm}^{-2}$ and different exposure times. Germination capacity on Petri dish test increased only in one lot of seeds after exposure for 1 and $5 \mathrm{~min}$. Increase in seedling emergence in the field experiment in the result of laser treatment occurred only in one seed lot. One-min laser treatment increased contents of chlorophylls and carotenoids in 8-day cotyledons (laboratory test) and in the second true leaves (field experiment).
\end{abstract}

Key words: He-Ne laser light, seed quality, germination capacity, field emergence, photosynthetic pigments

\section{INTRODUCTION}

Scorzonera belongs to the family Asteraceae. Depending on the planned use, it can be grown as an annual or a biennial plant. In the first year of cultivation, it forms a rosette of leaves and an edible black root, being similar in taste to the asparagus, while in the second an inflorescence and seeds. In Poland, mainly roots are consumed, but in other countries, including France and Spain, scorzonera leaves are used as a component of salads (Chaux \& Foury 1994; Nuez \& Bermejo 1994).

Scorzonera is also used in the traditional medicine of Europe and Asia, due to its nutrient (sodium, calcium, magnesium, phosphorus, iron, carotene, vitamins $\mathrm{C}, \mathrm{B}_{1}, \mathrm{~B}_{2}$, polyphenolic acids and glycosides, especially inulin) as well as dietary values (Chaux \& Foury 1994).
Seed quality is an important parameter determining the efficiency of crop production. It depends on several factors, including selection of seeds, the environmental conditions during the development of mother plants or storage conditions (Grzesik et al. 2012). Seeds used as sowing material must be of the quality, ensuring proper plant density in the field and ultimately a high yield of crops.

For these reasons, different measures of seed quality improvement were proposed. These include chemical (seed dressings, growth regulators, etc.) or physical methods (alternating magnetic field, laser irradiation, etc.) (Dziwulska-Hunek et al. 2009; Gładyszewska 2011).

In the recent times, pre-sowing stimulation of seeds with laser light has become a popular method of improving the sowing material. This method is especially popular in organic farming, as it is safe for the natural environment (Hernandez et al. 2010). 
However, there are not many studies on the effect of laser light on the germination and growth of plants that would involve longer times of exposure. The research reports available are focused mainly on cereals (spring barley) and oil-bearing plants (rapeseed) (Rybiński 2001; Starzycki et al. 2005).

Literature data indicate that pre-sowing laser light stimulation of seeds of various plant species improves their germination capacity, emergence rate and yields (Ćwintal \& Dziwulska-Hunek 2013; Krawiec \& Dziwulska-Hunek 2009; Hernandez et al. 2010; Podleśna et al. 2015). Stimulation with laser light can also cause an increase in the content of photosynthetic pigments (Dziwulska-Hunek et al. 2013; Sacała et al. 2012). The objective of this study was to determine the effect of presowing laser light stimulation of scorzonera seeds of varied quality on germination and seedling emergence, and the content of photosynthetic pigments.

\section{MATERIALS AND METHODS}

The experimental material consisted of seeds of scorzonera cv. 'Duplex' from the harvests of 2010, 2011 and 2012 (denoted as seed lots 1, 2 and 3 , respectively). Seeds of different harvest years were stored in a refrigerator at $5{ }^{\circ} \mathrm{C}$.

The seeds were subjected to presowing stimulation with $\mathrm{He}-\mathrm{Ne}$ laser light with the power of $40 \mathrm{~mW}$ and wavelength of $632.8 \mathrm{~nm}$, surface power density of $5 \mathrm{~mW} \cdot \mathrm{cm}^{-2}$ and exposure times of 0 (control), 1, 5, 10 and 30 min (denoted as C, L1, L5, L10 and L30, respectively). The process of seed stimulation was con-ducted with the use of an apparatus generating adjustable doses of energy (Koper 1996). The beam of $\mathrm{He}-\mathrm{Ne}$ laser light was applied from above on seeds arranged in a single-seed layer (distance from seeds $0.3 \mathrm{~m}$ ).

Two experiments were held: in a laboratory and a field. The laboratory experiment was conducted in a lab room at temperature of $20^{\circ} \mathrm{C} \pm 1{ }^{\circ} \mathrm{C}$ and in the presence of fluorescent light of the intensity 550-570 lx) in the photoperiod of 12/12 h. After laser stimulation, the seeds were placed on Petri dishes lined with three layers of filter paper moistened with dis-tilled water. The experiment was performed in four replicates of 50 seeds each (200 seeds per treatment). Germination capacity (as \% of typical seedlings) and pigment content were determined after 8 days. Cotyledons were collected at random from the Petri dishes and used for assays of chlorophylls $\mathrm{a}$ and $\mathrm{b}$ and carotenoids. The pigments were isolated in darkness, in acetone with an addition of $0.01 \% \mathrm{w} / \mathrm{v}$ BHT (butylated hydroxytoluene) to avoid pigment oxidation. UV-Vis spectra were measured with the help of a twin-beam spectrophotometer Carry Bio 300 and analyzed in conformance with the procedure published by Lichtenthaler and Buschmann (2001). Measurement of photosynthetic pigment contents in each experimental variant was done in triplicate.

The field experiment was conducted at the Felin Experimental Farm of the University of Life Sciences in Lublin $\left(51^{\circ} 23^{\prime} \mathrm{N}, 22^{\circ} 56^{\prime} \mathrm{E}\right)$ on a greybrown podzolic soil developed from loess formations over lying chalk marls, with a grain size composition corresponding to that of weak silty loams. The sowing date of scorzonera seeds was 24 April 2013. The field experiment was set up in four replications of 100 seeds on micro-plots of $2 \mathrm{~m}^{2}$ surfaces $(2.5 \times 0.8 \mathrm{~m})$. The emergence of seedlings was determined after 3 weeks from a seed sowing date. In the field experiment, samples of the true second leaves (one sample was 5 leaves) for pigments analyses were collected at random from the micro-plots at the initial phase of plant development, 30 days after sowing.

After sowing the seeds (24 April 2013), air temperature was significantly higher than the longterm average for this period. In conjunction with the appropriate amount of precipitation in the period since the third decade of April to the second decade of May, there were favor-able conditions for quick and uniform field emergence of this plant.

The results obtained were processed statistically using the analysis of variance ANOVA (Statistica 12.0). Intervals of confidence were determined with the Dunnett's test at the level of $\alpha=0.05$. The results were analyzed statistically, separately for each lot of seeds. All the experimental data variants concerning seeds stimulated by laser light were compared to control (untreated seeds). 


\section{RESULTS AND DISCUSSION}

The germination percentage after 8 days on $\mathrm{Pe}$ tri plates of control seeds was 73.0, 65.0 and $89.0 \%$ respectively for lots 1,2 and 3 (Table 1). The exposure of these seeds on laser light in-creased the germination ability by about $40 \%$ only in lot 2 after 1 and 5 min exposure.

Seedling emergence of control seeds in the field was from 34.5 to $38.0 \%$ depending on the seed lot. Laser stimulation was noted only for lot 1 by 21 $25 \%$, depending on exposure time (Table 1).

The examined seeds came from different collection years and were characterized by different initial germination capacity in Petri plates and seedling emergence in the field. Irradiation of seeds with laser light improved to some ex-tent germination only in the result of 1 and $5 \mathrm{~min}$ exposure of one seed lot. These results were not consistent with studies of Krawiec et al. (2015) on scorzonera seeds cv. 'Maxima'. In that study, a significantly positive ef- fect of irradiation of seeds with laser light on the germination of seeds with low and medium initial germination capacity (50.8-79.3\%) was reported. On the other hand, seeds showing a high initial germination capacity $(93 \%)$ reacted with the decrease of this parameter to laser radiation.

It might show a specific reaction of cultivars for laser stimulation The seeds of different crop species and cultivars reacted differently to the presowing laser stimulation. Significantly positive effect of laser radiation on the germination of seeds was found in white lupine (Podleśny \& Koper 1998), white clover (Dziwulska et al. 2004), radish (Muszyński \& Gładyszewska 2008), cucumber cultivars: 'Delicius', 'Hela F ', 'Krak F ' and 'Racibor $F_{1}$ ' (Szajsner \& Drozd 2007) and tomato cultivar 'Promyk' (Klimont 2002). No positive effect was observed in oats (Drozd \& Szajsner 2007), sugar beet (Prośba-Białczyk et al. 2013), cucumber 'Polan $\mathrm{F}_{1}$ ' and tomato 'Betalux' (Klimont 2002) and pepper (Szajsner \& Drozd 2007).

Table 1. Effect of laser light treatment on seed germination on Petri plates after 8 days and on field emergence of scorzonera 'Duplex' seedlings after 30 days (\%)

\begin{tabular}{cllllll}
\hline \multirow{2}{*}{$\begin{array}{c}\text { Seed } \\
\text { lots }\end{array}$} & \multicolumn{5}{c}{ Exposure time (min) } \\
\cline { 2 - 7 } & \multicolumn{1}{c}{$\mathrm{C}$} & $\mathrm{L} 1$ & $\mathrm{~L} 5$ & L10 & L30 \\
\hline \multirow{2}{*}{1} & Germination capacity & $73 \mathrm{a} \pm 8.87$ & $81 \mathrm{a} \pm 3.83$ & $72 \mathrm{a} \pm 8.00$ & $81 \mathrm{a} \pm 12.38$ & $82 \mathrm{a} \pm 6.93$ \\
\cline { 2 - 7 } & Field emergence & $34.5 \mathrm{e} \pm 3.00$ & $41.8 \mathrm{~d} \pm 5.06$ & $42.3 \mathrm{~b} \pm 4.35$ & $43.3 \mathrm{a} \pm 3.20$ & $42 \mathrm{c} \pm 5.16$ \\
\hline \multirow{2}{*}{2} & Germination capacity & $65 \mathrm{c} \pm 8.25$ & $90 \mathrm{~b} \pm 7.66$ & $91 \mathrm{a} \pm 6.83$ & $76 \mathrm{c} \pm 4.08$ & $72 \mathrm{c} \pm 12.65$ \\
\cline { 2 - 7 } & Field emergence & $38.0 \mathrm{a} \pm 3.65$ & $42.3 \mathrm{a} \pm 5.56$ & $45.5 \mathrm{a} \pm 8.54$ & $39.8 \mathrm{a} \pm 1.71$ & $37.3 \mathrm{a} \pm 4.43$ \\
\hline \multirow{2}{*}{3} & Germination capacity & $89 \mathrm{a} \pm 5.66$ & $77 \mathrm{a} \pm 15.45$ & $77 \mathrm{a} \pm 10.52$ & $83 \mathrm{a} \pm 13.61$ & $78 \mathrm{a} \pm 5.16$ \\
\cline { 2 - 7 } & Field emergence & $34.8 \mathrm{a} \pm 6.70$ & $35.0 \mathrm{a} \pm 6.63$ & $37.0 \mathrm{a} \pm 3.83$ & $41.8 \mathrm{a} \pm 5.56$ & $39.5 \mathrm{a} \pm 2.38$ \\
\hline
\end{tabular}

C - control, untreated seeds, L1, L5, L10, L30 - seeds subjected to laser stimulation with He-Ne light of $\lambda=632.8$ $\mathrm{nm}$, density power of $5 \mathrm{~mW} \cdot \mathrm{cm}^{-2}$ and exposure time $1,5,10$ and 30 minutes;

\pm standard deviation; means followed with different letters in the same line are statistically different compared to control using Dunnett's, $\alpha=0.05$.

Table 2. Effect of laser light treatment on chlorophyll a ( $\mu \mathrm{g} \cdot \mathrm{g}^{-1}$ of green mass ) content in of 8-days old cotyledons of scorzonera 'Duplex' (Petri dishes)

\begin{tabular}{cccccc}
\hline \multirow{2}{*}{ Seed lots } & \multicolumn{5}{c}{ Exposure time (min) } \\
\cline { 2 - 6 } & $\mathrm{C}$ & L1 & L5 & L10 & L30 \\
\hline 1 & $131 \mathrm{e} \pm 0.68$ & $205 \mathrm{a} \pm 1.52$ & $139 \mathrm{~d} \pm 0.70$ & $154 \mathrm{~b} \pm 0.37$ & $150 \mathrm{c} \pm 0.45$ \\
\hline 2 & $144 \mathrm{~d} \pm 2.13$ & $208 \mathrm{a} \pm 2.02$ & $111 \mathrm{e} \pm 0.58$ & $156 \mathrm{~b} \pm 0.84$ & $153 \mathrm{c} \pm 1.22$ \\
\hline 3 & $126 \mathrm{~b} \pm 0.53$ & $147 \mathrm{a} \pm 0.55$ & $108 \mathrm{c} \pm 1.04$ & $102 \mathrm{~d} \pm 0.43$ & $88 \mathrm{e} \pm 0.50$ \\
\hline
\end{tabular}

Explanations as in Table 1. 
In our experiment, laser improved seedling emergence only in the oldest seeds. Krawiec et al. (2015) obtained similar results with scorzonera 'Maxima'. In their studies, only the seeds of the lowest initial germination capacity reacted to $\mathrm{He}-$ $\mathrm{Ne}$ laser pre-sowing irradiation with the increase of seedling emergence in the field.

Several studies performed on various crop plants showed that the effects of laser stimulation can depend on many factors: the wave-length, dose, exposure time, the species and cultivar of plant (Rybiński 2001; Klimont 2002; Hernandez et al. 2010; Gładyszewska 2011). The results of our study show that the differences in the responses can vary, depending on the quality of seeds. Thus, chlorophyll a content in cotyledons increased in the result of $1 \mathrm{~min}$ laser exposure in all seed lots by 56,44 and $16 \%$ depended on the lot, the most for the oldest seeds (Table 2). Similar tendency was in content of $\beta$-chlorophyll, where increases were by 64,30 and $12 \%$ (Table 3 ). The contents of chlorophylls of the oldest seeds increased also by exposure of 5, 10 and $30 \mathrm{~min}$ but to the lesser extent. Younger seeds reacted to higher laser doses with decrease of chlorophyll contents. The same tendency in contents of chlorophyll in the second true leaves in the field cultivation but increase was lower from 29 to $12 \%$, depending on chlorophyll type and seed lot (Table 5 \& 6). One-min exposure stimulated increase of carotenoids content from 21 to $54 \%$ (cotyledons) and 30 to $12 \%$ (second true leaves) (Tables $4 \& 7$ ).

There are no reports on the effect of laser light stimulation on the content of chlorophylls and carotenoids in seedlings and young plants in an experimental system like that applied in our study. The authors of other reports used different kinds of lasers and incomparable times of exposure, and they conducted the as-says on the content of pigments after a significantly longer period of time.

Resuming, presowing stimulation of scorzonera seeds 'Duplex' with laser light produces an increase in the chlorophyll and carotenoid content in cotyledons and second true leaves of the seedlings. There was no clear effect of laser application on germination and seedling emergence.

Table 3. Effect of laser light treatment on chlorophyll $b\left(\mu \mathrm{g} \cdot \mathrm{g}^{-1}\right.$ of green mass) content in of 8-day-old cotyledons of scorzonera 'Duplex' (Petri dishes)

\begin{tabular}{cccccc}
\hline \multirow{2}{*}{ Seed lots } & \multicolumn{5}{c}{ Exposure time (min) } \\
\cline { 2 - 6 } & $\mathrm{C}$ & L1 & L5 & L10 & L30 \\
\hline 1 & $45 \mathrm{e} \pm 0.27$ & $74 \mathrm{a} \pm 2.21$ & $51 \mathrm{~d} \pm 0.73$ & $54 \mathrm{~b} \pm 1.84$ & $53 \mathrm{c} \pm 2.15$ \\
\hline 2 & $53 \mathrm{~b} \pm 1.17$ & $69 \mathrm{a} \pm 1.01$ & $38 \mathrm{c} \pm 0.55$ & $54 \mathrm{~b} \pm 0.94$ & $53 \mathrm{~b} \pm 0.93$ \\
\hline 3 & $42 \mathrm{~b} \pm 0.65$ & $47 \mathrm{a} \pm 0.55$ & $37 \mathrm{c} \pm 0.23$ & $36 \mathrm{~d} \pm 0.80$ & $31 \mathrm{e} \pm 0.71$ \\
\hline
\end{tabular}

Explanations as in Table 1.

Table 4. Effect of laser light treatment on carotenoid $\left(\mu \mathrm{g} \cdot \mathrm{g}^{-1}\right.$ of green mass) content in of 8-day-old cotyledons of scorzonera 'Duplex' (Petri dishes)

\begin{tabular}{cccccc}
\hline \multirow{2}{*}{ Seed lots } & \multicolumn{5}{c}{ Exposure time (min) } \\
\cline { 2 - 6 } & $\mathrm{C}$ & L1 & L5 & L10 & L30 \\
\hline 1 & $24 \mathrm{~d} \pm 0.64$ & $30 \mathrm{a} \pm 1.02$ & $23 \mathrm{~d} \pm 0.72$ & $29 \mathrm{~b} \pm 0.41$ & $26 \mathrm{c} \pm 1.06$ \\
\hline 2 & $24 \mathrm{c} \pm 0.37$ & $37 \mathrm{a} \pm 0.71$ & $20 \mathrm{~d} \pm 0.36$ & $27 \mathrm{~b} \pm 0.24$ & $25 \mathrm{c} \pm 0.54$ \\
\hline 3 & $22 \mathrm{~b} \pm 1.43$ & $31 \mathrm{a} \pm 0.46$ & $23 \mathrm{~b} \pm 0.57$ & $21 \mathrm{~b} \pm 0.32$ & $19 \mathrm{c} \pm 0.24$ \\
\hline
\end{tabular}

Explanations as in Table 1. 
Table 5. Effect of laser light treatment on chlorophyll $a\left(\mu \mathrm{g} \cdot \mathrm{g}^{-1}\right.$ of green mass) content in scorzonera 'Duplex' seedlings after 30 days (field)

\begin{tabular}{cccccc}
\hline \multirow{2}{*}{ Seed lots } & \multicolumn{5}{c}{ Exposure time (min) } \\
\cline { 2 - 6 } & $\mathrm{C}$ & L1 & L5 & L10 & L30 \\
\hline 1 & $670 \mathrm{e} \pm 0.26$ & $813 \mathrm{a} \pm 4.85$ & $747 \mathrm{c} \pm 7.13$ & $719 \mathrm{~d} \pm 3.43$ & $809 \mathrm{~b} \pm 3.05$ \\
\hline 2 & $721 \mathrm{~b} \pm 5.90$ & $811 \mathrm{a} \pm 0.99$ & $701 \mathrm{c} \pm 14.67$ & $666 \mathrm{e} \pm 5.91$ & $676 \mathrm{~d} \pm 8.47$ \\
\hline 3 & $691 \mathrm{~d} \pm 7.30$ & $893 \mathrm{a} \pm 5.05$ & $842 \mathrm{~b} \pm 8.41$ & $699 \mathrm{~d} \pm 27.33$ & $795 \mathrm{c} \pm 6.23$ \\
\hline
\end{tabular}

Explanations as in Table 1.

Table 6. Effect of laser light treatment on chlorophyll $b\left(\mu \mathrm{g} \cdot \mathrm{g}^{-1}\right.$ of green mass) content in scorzonera 'Duplex' seedlings after 30 days (field)

\begin{tabular}{cccccc}
\hline \multirow{2}{*}{ Seed lots } & \multicolumn{5}{c}{ Exposure time (min) } \\
\cline { 2 - 6 } & $\mathrm{C}$ & L1 & L5 & L10 & L30 \\
\hline 1 & $201 \mathrm{e} \pm 9.63$ & $244 \mathrm{a} \pm 2.06$ & $225 \mathrm{c} \pm 0.69$ & $215 \mathrm{~d} \pm 0.25$ & $237 \mathrm{~b} \pm 0.40$ \\
\hline 2 & $212 \mathrm{~b} \pm 1.39$ & $242 \mathrm{a} \pm 1.03$ & $208 \mathrm{~b} \pm 3.65$ & $197 \mathrm{c} \pm 0.80$ & $197 \mathrm{c} \pm 2.24$ \\
\hline 3 & $214 \mathrm{~d} \pm 1.21$ & $268 \mathrm{a} \pm 3.36$ & $267 \mathrm{~b} \pm 0.82$ & $202 \mathrm{e} \pm 7.41$ & $239 \mathrm{c} \pm 0.77$ \\
\hline
\end{tabular}

Explanations as in Table 1.

Table 7. Effect of laser light treatment on carotenoids ( $\mu \mathrm{g} \cdot \mathrm{g}^{-1}$ of green mass) content in scorzonera 'Duplex' seedlings after 30 days (field)

\begin{tabular}{cccccc}
\hline \multirow{2}{*}{ Seed lots } & \multicolumn{5}{c}{ Exposure time (min) } \\
\cline { 2 - 6 } & $\mathrm{C}$ & L1 & L5 & L10 & L30 \\
\hline 1 & $105 \mathrm{c} \pm 6.57$ & $131 \mathrm{a} \pm 0.42$ & $117 \mathrm{~b} \pm 3.64$ & $114 \mathrm{c} \pm 6.05$ & $112 \mathrm{c} \pm 2.02$ \\
\hline 2 & $117 \mathrm{~b} \pm 5.68$ & $131 \mathrm{a} \pm 2.57$ & $112 \mathrm{~b} \pm 6.95$ & $106 \mathrm{c} \pm 0.51$ & $109 \mathrm{~b} \pm 4.95$ \\
\hline 3 & $112 \mathrm{~d} \pm 2.89$ & $145 \mathrm{a} \pm 3.83$ & $133 \mathrm{~b} \pm 1.51$ & $109 \mathrm{~d} \pm 0.48$ & $132 \mathrm{c} \pm 3.39$ \\
\hline
\end{tabular}

Explanations as in Table 1.

\section{REFERENCES}

Chaux C., Foury C. 1994. Scorsonère ou salsifi noir. In: Productions légumières, vol. 2. Technique et Documentation - Lavoisier, Paris, pp. 443-451.

Cuttriss A., Pogson B. 2004. Carotenoids. In: Davies K.M. (Ed.), Plant pigments and their manipulation. Blackwell Publishing, Oxford, UK, pp. 57-91.

Ćwintal M., Dziwulska-Hunek A. 2013. Effect of electromagnetic stimulation of alfalfa seeds. International Agrophysics 27: 391-401. DOI: 10.2478/intag-2013-0009.

Drozd D., Szajsner H. 2007. Effect of application of presowing laser stimulation on bare-grained oat genotypes. Acta Agrophysica 9(3): 583-589. [in Polish with English abstract]

Dziwulska A., Koper R., Wilczek M. 2004. Estimation of effect of He-Ne laser beam on germination capacity of white clover variety of Anda cultivar. Acta
Agrophysica 3(3): 435-441. [in Polish with English abstract]

Dziwulska-Hunek A., Kornarzyński K., Matwijczuk A, Pietruszewski S., Szot B. 2009. Effect of laser and variable magnetic field stimulation on amaranth seeds germination. International Agrophysics 23: 229-235.

Dziwulska-Hunek A., Sujak A., Kornarzyński K. 2013. Short-term exposure to pre-sowing electromagnetic radiation of amaranth seeds affects germination energy but not photosynthetic pigment content. Polish Journal of Environmental Studies 22(1): 93-98.

Gładyszewska B. 2011. Estimation of a laser biostimulation dose. International Agrophysics 25: 403-405.

Grzesik M., Janas R., Górnik K., Romanowska-Duda Z. 2012. Biological and physical methods of seed production and processing. Journal of Research and Applications in Agricultural Engineering 57(3): 147-152. [in Polish with English abstract] 
Hernandez A.C., Dominguez P.A., Cruz O.A., Ivanov R., Carballo C.A., Zepeda B.R. 2010. Laser in agriculture. International Agrophysics 24: 407-422.

Klimont K. 2002. Studies of laser biostimulation on sowing value of seeds and yield of tomato (Lycopersicon esculentum Mill.) and cucumber (Cucumis sativus L.) plants. Bulletin of Plant Breeding and Acclimatization Institute 223/224: 257-266. [in Polish with English abstract]

Koper R. 1996. (54) Urządzenie do przedsiewnej laserowej biostymulacji nasion metodą ich naświetlania nastawnymi dawkami energii. Patent UPRP, 296303. WUP 07/96. [in Polish]

Krawiec M., Dziwulska-Hunek A. 2009. Effect of presowing laser stimulation on germination of pea seeds (Pisum sativum L.) and field emergence. Advances of Agricultural Sciences Problem Issues 539: 359-364. [in Polish with English abstract]

Krawiec M., Dziwulska-Hunek A., Sujak A., Palonka S. 2015. Laser irradiation effects on scorzonera (Scorzonera hispanica L.) seed germination and seedling emergence. Acta Scientiarum Polonorum Hortorum Cultus 14(2): 145-158.

Lichtenthaler H.K., Buschmann C. 2001. Chlorophylls and carotenoids: measurement and characterization by UV-VIS spectroscopy. Current Protocols in Food Analytical Chemistry, Supplement 1: F4.3.1F4.3.8. DOI: 10.1002/0471142913.faf0403s01.

Muszyński S., Gładyszewska B. 2008. Representation of He-Ne laser irradiation effect on radish seeds with selected germination indices. International $\mathrm{Ag}$ rophysics 22: 151-157.

Nuez F., Hernández Bermejo J.E. 1994. Neglected horticultural crops. In: Hernández Bermejo J.E., León J. (Eds.), 1492 from a different perspective. FAO Plant Production and Protection Series no. 26, Rome, pp. 303-332.
Podleśny J., Koper R. 1998. Effectiveness of pre-sowing treatment of white lupine seeds with laser light. Zeszyty Problemowe Postępów Nauk Rolniczych 454: 255-262. [in Polish with English abstract]

Podleśna A., Gładyszewska B., Podleśny J., Zgrajka W. 2015. Changes in the germination process and growth of pea in effect of laser seed irradiation. International Agrophysics 29: 485-492. DOI: 10.1515/intag-2015-0054.

Prośba-Białczyk U., Szajsner H., Grzyś E., Demczuk A., Sacała E., Bąk K. 2013. Effect of seed stimulation on germination and sugar beet field. International Agrophysics 27: 195-201. DOI: 10.2478/v10247012-0085-8.

Rybiński W. 2001. Influence of laser beams combined with chemomutagen (MNU) on the variability of traits and mutation frequency in spring barley. International Agrophysics 15: 115-119.

Sacała E., Demczuk A., Grzyś E. Prośba-Białczyk U., Szajsner H. 2012. Impact of pre-sowing laser irradiation of seeds on sugar beet properties. International Agrophysics 26: 295-300. DOI: 10.2478/v10247-012-0042-6.

Starzycki M., Rybiński W., Starzycka E., Pszczoła J. 2005. Laser light as a physical factor enhancing rapeseed resistance to blackleg disease. Acta Agrophysica 5(2): 441-446.

Szajsner H., Drozd D. 2007. The improvement of seeds of selected vegetable species through laser radiation. Roczniki Akademii Rolniczej w Poznaniu CCCLXXXIII, Ogrodnictwo 41: 625-629. [in Polish with English abstract]

Willows R.D. 2004. Chlorophylls. In: Davies K.M. (Ed.), Plant pigments and their manipulation. Blackwell Publishing, Oxford, UK, pp. 23-46. 